6 - ORIGINAL ARTICLE

WOUND HEALING

\title{
Evaluation of the abdominal wall cicatrization of rabbits exposed to nicotine and undergone abdominoplasty using nylon thread or cyanoacrylate ${ }^{1}$
}

\author{
Avaliação da cicatrização da parede abdominal de coelhos expostos à nicotina e submetidos à \\ abdominoplastia, utilizando-se nylon ou cianocrilato
}

\begin{abstract}
Luciano Assis Costa ${ }^{\mathrm{I}}$, Paulo dos Reis Jardim, Pedro Henrique Alvares Paiva MacedoI, Vânia da Fonseca Amaral ${ }^{\mathrm{II}}$, Alcino Lázaro da Silva ${ }^{\text {III }}$, Cirênio de Almeida Barbosa ${ }^{\text {IV }}$

I'Graduate student, FCMMG, Minas Gerais, Brazil. Acquisition of data, manuscript preparation.

IIMaster, Assistant Professor, General Pathology, Institute of Biological Sciences, Federal University of Minas Gerais (UFMG), Brazil. Acquisition and interpretation of data.

IIIProfessor Emeritus of Surgery, Faculty of Medicine, UFMG, Brazil. Critical revision, final approval of the version to be published.

${ }^{\mathrm{IV}} \mathrm{PhD}$, Assistant Professor, Department of Surgical Technique and Experimental Surgery, Technical Operative and Video Surgery Unit "Professor Luiz Andrés Ribeiro de Oliveira", FCMMG, Brazil. Main author. Conception, design, scientific and intellectual content of the study, manuscript writing, critical revision.
\end{abstract}

\begin{abstract}
PURPOSE: To compare the wound healing of the abdominal wall of rabbits exposed to nicotine and submitted to abdominoplasty using 2-octyl cyanoacrylate or nylon thread for the surgery suture.

METHODS: Thirty two rabbits were used. They were divided in subgroups: A1, A2, B1 e B2. Group A received saline 0.9\%; group $\mathrm{B}$ received nicotine, both groups for 14 days before surgery. We performed an abdominoplasty with a nylon suture into the A1 and B1 subgroups; as for A2 and B2 groups the suture was performed with cyanoacrylate. The euthanasia happened in the $14^{\text {th }}$ post-operative day. After, we evaluated: swollen process, fibroblast proliferation, collagen, neovascularization, and macroscope and microscope epithelization of the scars.

RESULTS: We observed the presence of eosinophils in all scars exposed to the cyanoacrylate, and a significant increase of neovascularization in the subgroup B2 comparing to the A2 one ( $p=0.037)$. The other variables haven't showed any statistical difference. CONCLUSIONS: Nicotine hasn't influenced the swollen process, the fibroblast proliferation, the presence of collagen, neither the epithelialization. The neovascularization showed cicatricial immaturity when comparing group A2 to group B2. The eosinophils in the scars repaired with glue showed that the substance has acted as an allergen.
\end{abstract}

Key words: Abdominal Wall. Wound Healing. Nicotine. Nylons. Cyanoacrylates. Rabitts.

\section{RESUMO}

OBJETIVO: Comparar a cicatrização da parede abdominal de coelhos expostos à nicotina e submetidos à abdominoplastia utilizando 2-octil cianoacrilato ou nylon na síntese cirúrgica.

MÉTODOS: Utilizou-se 32 coelhos. Estes foram distribuídos em subgrupos: A1, A2, B1 e B2. O grupo A recebeu solução de NaCl $0,9 \%$; o B recebeu nicotina, ambos durante 14 dias do pré-operatório. Nos subgrupos A1 e B1 foi realizada abdominoplastia e sutura com "nylon"; enquanto A2 e B2 a síntese ocorreu com cianoacrilato. A eutanásia ocorreu no $14^{\circ}$ dia do pós-operatório. Na pesquisa avaliouse: processo inflamatório, proliferação fibroblástica, colágeno, neovascularização, epitelização macro e microscópica das cicatrizes.

RESULTADOS: Observou-se presença de eosinofilia em todas as cicatrizes expostas ao cianoacrilato, e aumento significativo da neovascularização no subgrupo B2 em comparação com o A2 ( $\mathrm{p}=0,037)$. Demais variáveis não apresentaram diferença estatística.

CONCLUSÕES: A nicotina não influenciou o processo inflamatório, a proliferação fibroblástica, a presença de colágeno e a epitelização. A neovascularização indicou imaturidade cicatricial na comparação dos grupos A2 e B2. A eosinofilia nas cicatrizes reparadas com cola indica que a substância atuou como alergeno.

Descritores: Parede Abdominal. Cicatrização. Nicotina. Nylons. Cianoacrilatos. Coelhos. 


\section{Introduction}

The wound healing of scars involves complex molecular and cells mechanisms that lead to the reconstruction of damaged tissue. This process may suffer negative actions from exogen substances. For example, tobacco smoking is known as a harmful factor for scars cicatrization ${ }^{1,2}$.

The effects of tobacco smoking on cicatrization are highly researched. Mosely and Finseth ${ }^{3}$ were the pioneers in researching and describing the harmful effects of tobacco smoking on scars cicatrization. Since then, it was observed that smokers show a greater risk of dehiscence of abdominal wounds ${ }^{4}$, necrosis of skin grafting $^{1}$ and worse cicatrization of ulcers in the lower limbs ${ }^{3}$. Nicotine is responsible for negative effects on the keratinocytes, the skin aging, cicatrization and in some dermatologic diseases ${ }^{5}$. However this substance was beneficial to the inflammatory response ${ }^{5}$.

The cyanoacrylates were synthesized for the first time in $1949^{6}$. They are substances that polymerize very fast when in contact with wounds, becoming a strong and flexible glue. Literature has many studies evaluating the usage of cyanoacrylate in surgery, some of them compare it to the traditional methods ${ }^{7}$.

The purpose is to compare the abdominal wall cicatrization of rabbits exposed to nicotine $(2 \mathrm{mg} / \mathrm{kg} /$ day) and submitted to abdominoplasty using different ways to repair the tissue: 2-octyl cyanoacrylate and nylon thread.

\section{Methods}

The research followed the guidelines and the resolution of the Federal Law number 6.638; as well as the International Guiding Principles for Biomedical Research Involving Animals (CIOMS), 1985. The research was submitted to the approval of the Committee on Animal Research and Ethics from Medical Sciences Faculty of Minas Gerais /Brazil (project number 021/09).

Thirty two New Zealand white rabbits were used, weighting $2.76 \mathrm{~kg}$ on average. The animals were divided in groups A and B, each group with 16 rabbits. Group A received saline $0.9 \%$ of daily subcutaneous injections, as for group B, it received $2 \mathrm{mg} / \mathrm{kg} /$ day of nicotine solution (Nicotine di-tartrate salt, Sigma, Saint Louis, Missouri, USA) subcutaneously into the dorsal area. The solutions were prepared in a sterile environment, aiming the acquisition of $50 \mathrm{ml}$ with $5 \mathrm{mg} / \mathrm{mL}$ vials. Both groups were divided in subgroups A1 and A2, B1 and B2. The subgroups $\mathrm{A} 1$ and $\mathrm{B} 1$ were submitted to the procedure with nylon suture. The subgroups A2 and B2 were submitted to the approximation of the surgery edges with glue (2-octyl cyanoacrylate). Group B was administered nicotine for 14 days before the surgery procedure. For group A, saline solution was administered for the same period. The euthanasia happened in the $14^{\text {th }}$ post-operative day for histological evaluation.

The anesthetic procedure was done by combining ketamine (Vetaset, Ford Dodge Laboratories, Iowa, USA) with xylazine (Coopazine, Coopers, Sao Paulo, Brazil) via intramuscular in just one syringe. We used $60 \mathrm{mg}$ to $80 \mathrm{mg} / \mathrm{kg}$ of the weight for the ketamine combined to $8 \mathrm{mg}$ to $15 \mathrm{mg} / \mathrm{kg}$ of the weight for xylazine.

An abdominal dermolipectomy was made in all animals. An incision in the shape of an ellipsis was made in the suprapubic area. The incision measured $4 \mathrm{~cm}$ in its horizontal axis and $2 \mathrm{~cm}$ in the largest vertical axis (Figure 1).

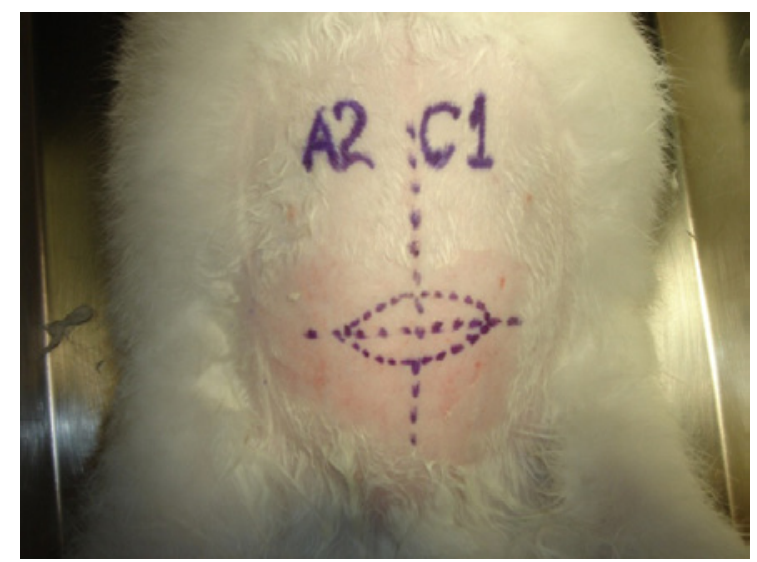

FIGURE 1 - Planning the incision in the shape of an ellipsis in the suprapubic area.

After that, all skin excess was removed and the homeostasis was done as well the approximation of the wound edges. In the subgroups A1 and B1, the repair was done with a 4-0 nylon thread. In the subgroups A2 and B2 the skin suture was made with 2-octyl cyanoacrylate (Figure 2).

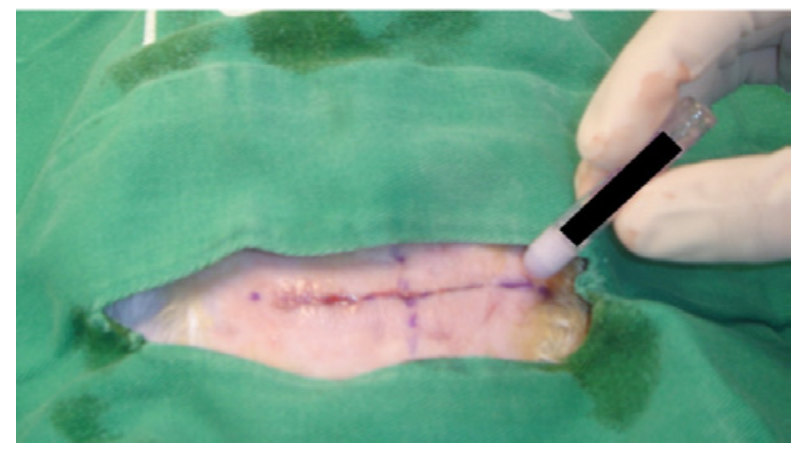

FIGURE 2 - Final appearance of the skin suture with 2-octyl cyanoacrylate. 
The removed skin was examined macroscopically and after that three fragments of each cutaneous snip were removed and they were processed to be included into paraffin. In the macroscopic exam we studied the epithelization and the presence of the operative wound dehiscence. Then, we made histological cuts to a thickness of $5 \mu \mathrm{m}$ and stained them with Hematoxylin Eosin and Gomori's Trichrome. The histological cuts were examined in an optical Nikon Eclipse E200 microscope with 4x, 10x, 40x objectives and 10x oculars and the histological variables studied were the fibroblast proliferation, the amount of collagen, the inflammatory infiltrated, the proliferation of capillaries and the resurfacing.

For the statistics analyses we used the Fisher's Exact Test and the Chi-squared Test. $5.0 \%$ or $\mathrm{p}=0.05$ was fixed as the rejection level of the null hypothesis.

For statistics the groups were compared as the following: $\mathrm{A} 1$ to $\mathrm{A} 2 ; \mathrm{A} 1$ to $\mathrm{B} 1 ; \mathrm{A} 2$ to $\mathrm{B} 2 ; \mathrm{B} 1$ to $\mathrm{B} 2$.

\section{Results}

The following table shows the results obtained after the anatomopathological analyses of the scars.

As for collagen presence in the analyzed scars (A1A2 $\mathrm{p}=0.315$; A1B $1 \mathrm{p}=0.565$; $\mathrm{A} 2 \mathrm{~B} 2 \mathrm{p}=0.440$; $1 \mathrm{~B} 2 \mathrm{p}=1.000)$, fibroblast proliferation (A1A2 $\mathrm{p}=0.248$; A1B1 $\mathrm{p}=0.574$; A2B2 $\mathrm{p}=0.809$; $\mathrm{B} 1 \mathrm{~B} 2 \mathrm{p}=0.247$ ), swollen process (A1A2 $\mathrm{p}=1.000$; A1B1 $\mathrm{p}=1.000$; $\mathrm{A} 2 \mathrm{~B} 2 \mathrm{p}=0.608$; B1B2 $\mathrm{p}=0.132$ ), macroscopic appearance of scars (A1A2 p=0.467; A1B1 p=1.000; A2B2 p=1.000; B1B2 p=0.200), as well as the epithelization microscopic analyses (A1A2 $\mathrm{p}=0.077$; A1B1 $p=0.619$; A2B2 $p=0.569$; B1B2 $p=0.119$ ) there were no statistically significant differences among the groups.

TABLE 1 - Vascularization observed in the studied scars.

\begin{tabular}{|c|c|c|c|c|}
\hline \multirow[b]{2}{*}{ Groups } & \multicolumn{3}{|c|}{ Vascularization } & \multirow[b]{2}{*}{ TOTAL } \\
\hline & $\begin{array}{c}\text { Less than } 5 \\
\text { capillaries } \\
\text { per field }\end{array}$ & $\begin{array}{c}5 \text { to } 10 \\
\text { capillaries } \\
\text { per field }\end{array}$ & $\begin{array}{c}\text { More } \\
\text { than } 10 \\
\text { capillaries } \\
\text { per field }\end{array}$ & \\
\hline $\mathrm{A} 1$ & 6 & 2 & 0 & 8 \\
\hline $\mathrm{A} 2$ & 6 & 1 & 1 & 8 \\
\hline B1 & 3 & 3 & 2 & 8 \\
\hline B2 & 1 & 2 & 5 & 8 \\
\hline Total & 16 & 8 & 8 & 32 \\
\hline
\end{tabular}

The result of the scars vascularization analyses (Table 1) showed $\mathrm{p}=0.037$ in comparison to the groups A2 and B2 indicating the presence of a larger number of neovessels in the presence of nicotine. There was no significant difference when comparing the other groups (A1A2 p=0.513; A1B1 $\mathrm{p}=0.202$; B1B2 $\mathrm{p}=0.289$ ). We observed that the nicotine and the 2-octyl cyanoacrylate combination have acted in a harmful way to the scar maturation.

The anatomopathological study showed the presence of eosinophils in all scars in which the 2-octyl cyanoacrylate was used in contrast with scars where the nylon thread was chosen to be the repair element ( $\mathrm{p}=0.000)$ (Figure 3 ).

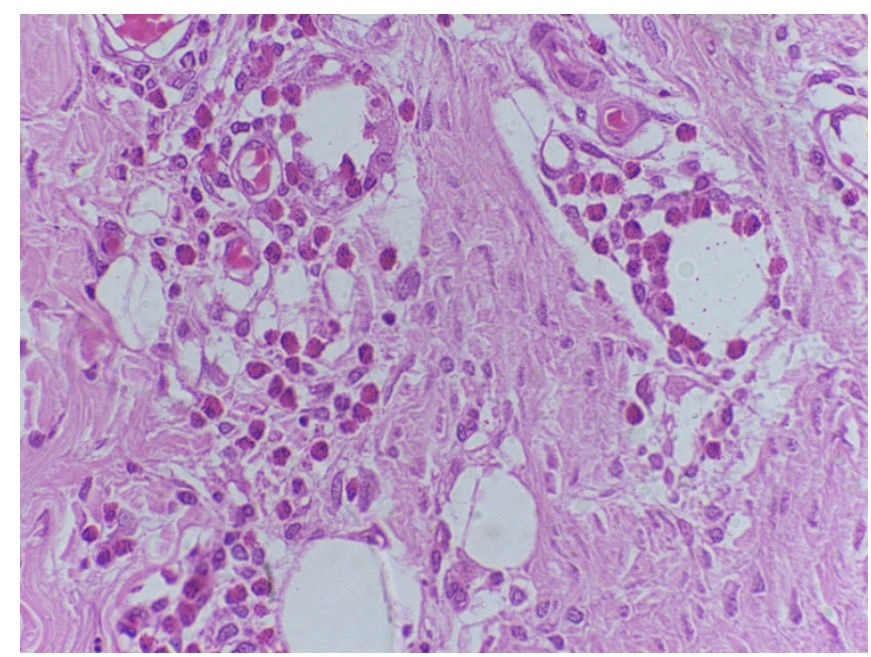

FIGURE 3 - Photomicrograph of cicatrization area showing the eosinophilic inflammatory infiltrate.

\section{Discussion}

When analyzing the skin graft cicatrization in rats' backs at laboratory, Forrest et al. ${ }^{8}$ used $2 \mathrm{mg} / \mathrm{kg}$ in two daily dosages for four weeks before surgery. They detected a decreasing of the capillary blood flow and of the distal perfusion of the area where the skin graft was done if compared to the control group. However, the negative effect of nicotine wasn't observed if the exposure to alkaloid had been done for only two weeks before surgery, showing that the harmful effects are dependent on the time of exposure to the nicotine solution.

Studying about the strain on rabbit's vesical wall after sutures, Machado et al. ${ }^{9}$ used $2 \mathrm{mg} / \mathrm{kg} /$ day of nicotine solution to reproduce serum levels of substances similar to the ones of a chronic smoker during a period of 28 days before the surgery. It was observed a decreasing in the number of neutrophils in the 4th post-operative day and an increase of plasma cells in the seventh post-operative day. There was no difference in the percentage of collagen type 1 and type 3 and in the strain of the cicatricial tissue.

Contrary to other streams, Morimoto et al. ${ }^{10}$ observed that nicotine on low dosages lead to angiogenesis and promote 
cicatrization, possibly because it hasn't reached the toxic serum levels or even due to the time of exposure to the agent was not enough to produce alteration into the cell physiology.

In this study, we have found scars with a larger number of neovessels in group B2 in relation to group A2. It is known that the proliferation of neovessels is an essential process to cicatrization. This proliferation begins in the final inflammatory phase and it intensifies in the fibroproliferative phase, but after around 14 days this vascularization begins to recede to be replaced by the definite vasculature that will nourish the formed tissue. As the anatomopathological pieces were removed in the 14th post-operative day, we observed that the subgroup B2 showed scars with vascularization compatible to a younger tissue morphophysiology. Also, it could be observed the presence of negative effects of nicotine with a $2 \mathrm{mg} / \mathrm{kg}$ /day dosage (giving for 14 days) in combination with 2-octyl cyanoacrylate in rabbits that were submitted to abdominoplasty. We have not found any literature that would corroborate to the harmful effect of this combination.

Sorensen et al. ${ }^{11}$ have evaluated the tissue (5mm) obtained by punch biopsy of the side area of 48 smokers' sacrum and 30 individuals that have never smoked. After one week the wounds were excised and corrected. The wound and excision sequence was repeated after four, eight and 12 weeks. The study showed that after interrupting tobacco smoking there have been an increase of infiltration of inflammatory cells and macrophages in the wounds. The neovascularization was not affected by the continuing tobacco smoking or by its abstinence. The wound inflammation and the proliferation of fibroblasts were attenuated in the smokers, which suggest a delay in the cicatrization. Smoking abstinence has recovered the inflammation, but it didn't affect the cell proliferation. Tobacco smoking seems to reduce the wound infection but not the dehiscence of the wound.

Biondo-Simões et al. ${ }^{12}$ reported in a study in which the cicatrization and collagen deposition were evaluated in rats exposed to nicotine $(2 \mathrm{mg} / \mathrm{kg}$ /day during seven days before surgery was done and kept for seven or 14 days in post-operative) refer to the copious finding of collagen type 3 in the control group, and that may cause cicatricial immaturity ${ }^{2,10,13}$.

Also Biondo-Simões et al. ${ }^{14}$ in an experiment to evaluate rats' abdominal cicatrization observed that nicotine provokes a reduction in the fibroblast population, without modifying significantly the collagen density tough.

Different studies show the biocompatibility of synthetic glues comparing them to the traditional ways of surgical suture. Although, there are several reports of increasing in the inflammatory activity ${ }^{15}$, skin necrosis ${ }^{16}$ and contact dermatitis ${ }^{17}$ combined to the usage of cyanoacrylates.

It wasn't observed statistically significant differences among the scars in which the nylon thread and 2-octyl cyanoacrylate were used, as well as the collagen amount, the epithelization and the inflammatory process. According to Batista et al. ${ }^{7}$, there were no differences in the aponeuroses scars morphology of the rabbits' abdominal wall when compared to the n-butil-2-cyanoacrylate adhesive and the monofilament nylon thread 3-0, however, the suture with adhesive was faster and more resistant to the strength of the rupture test in the $14^{\text {th }}$ day than the suture with the thread. Shimizu et al. ${ }^{18}$ also observed that the adherence of the skin graft in rats with n-butyl cyanoacrylate has showed the same results as the one with suture.

Although the finding of significant eosinophils in the glued scars in this experiment, Alferes et al. ${ }^{19}$ observed that the usage of ethyl-2-cyanoacrylate was a good option to the suture of the skin and they showed a proper biocompatibility. These authors, however, don't recommend the isolated usage of cyanoacrylate in wounds that show strain, the way we have developed in this present study.

In a study that involved 200 patients, D'Assumpção ${ }^{20}$ has observed that the usage of glue (Super-Bonder ${ }^{\circledR}$ ) showed less complication than the usage of surgical threads. He recommends it in the daily usage for most of plastic surgeries.

From the studied scars we have observed the presence of eosinophils infiltrated in all scars in which there was glue (A2 and B2), this suggests that it has acted as an allergen. According to Tomb et al. ${ }^{17}$ the usage of cyanoacrylate may present an adverse event to the presence of contact dermatitis that corroborate to our findings.

\section{Conclusions}

Nicotine injected subcutaneously in rabbits submitted to abdominoplasty hasn't showed significant differences to the study of collagen presence, fibroblast proliferation, swollen process, epithelization and the macroscopic appearance of the scar in relation to the control group.

\section{References}

1. Rees TC, Liverett DM, Guy CI. The effect of cigarette smoking on skin flap survival in the face lift patient. Plast Reconstr Surg 1984;73:911-5.

2. Medeiros AC, Lima FP, Dantas Filho AM, Melo NMC, Azevedo IM. A nicotina atua como fator deletério na reparação da parede abdominal. Acta Cir Bras. 2003;18(1):19-23.

3. Mosely L, Finseth F. Cigarette smoking: impairment of digital blood 
Evaluation of the abdominal wall cicatrization of rabbits exposed to nicotine and undergone abdominoplasty using nylon thread or cyanoacrylate

flow in the hand. Hand. 1977;98:97-101.

4. Abbas SM, Hill AG. Smoking is a major risk factor for wound dehiscence after midline abdominal incision; case-control study. ANZ J Surg. 2009;79(4):247-50.

5. Misery L. Nicotine effects on skin: Are they positive or negative? Exp Dermatol. 2004;13;665-70.

6. Fagundes DJ, Taha MO, Rivoire HC. Adesivos cirúrgicos: revisão e atualização. JBM. 2002;82(3):101-3.

7. Batista CAM, Colleoni Neto R, Lopes Filho GJ. Comparative study of the healing process of the aponeurosis of the anterior abdominal wall of rats after wound closure using 3-0 nylon suture and N-butil2-cyanoacrylate tissue adhesive. Acta Cir Bras. 2008;23(4):352-63.

8. Forrest CR, Pang CY, Lindsay WK. Dose and time effects of nicotine treatment on the capillary blood flow and viability of random pattern skin flaps in the rat. Br J Plast Surg. 1987;40(3):295-9.

9. Machado C, Chin EWK, Ioshii SOI, Filho RT, Bathen AV. Influence of nicotine on healing of vesical sutures in rabbits. Acta Cir. Bras. 2007;22 (6):479-84

10. Morimoto N, Takemoto S, Kawazoe T, Suzuki S. Nicotine at a low concentration promotes wound healing. J Surg Res. 2008;145(2):199-204.

11. Sorensen LT, Toft B, Rygaard J, Ladelund S, Teisner B, Gottrup F. Smoking attenuates wound inflammation and proliferation while smoking cessation restores inflammation but not proliferation. Wound Repair Regen. 2010;18(2):186-92.

12. Biondo-Simões MLP, Tetilla MR, Biondo-Simões R, Marlin MM, Repka JCD, Zanato D. The influence of nicotine on the density of collagen in cutaneous scars in rats. Rev Col Bras Cir. 2009;36(5):425-30.

13. Junqueira LC, Cossemelli W, Bretani R. Differential staining of collagen type I, II and III by Sirius Red and polarization microscopy. Arch Histol Jpn. 1978;41(3):267-74.

14. Biondo-Simões MLP, Spelling NW, Ioshii SII, Biondo-Simões R, Repka JCD. The influence of nicotine on the population of fibroblasts in cutaneous scars in rats. Acta Cir Bras. 2009;24(6):466-70.

15. Tseng YC, Hyon SH, Ikada Y, Shimizu Y, Tamura K, Hitomi S. In vivo evaluation of 2-cyanoacrylates as surgical adhesives. J Appl Biomater. 1990;1(2):111-9.

16. Wang AA, Martin CH. Full-thickness skin necrosis of the fingertip after application of superglue. J Hand Surg. 2003;28(4):696-8.

17. Tomb RR, Lepoittevin JP, Durepaire F, Grosshans E. Ectopic contact dermatitis from ethyl-cyanoacrylate instant adhesives. Contact Dermatitis. 1993;28(4):206-8.

18. Shimizu RK, Rahal SC, Sequeira JL. Use of n-butyl cyanoacrylate glue with single pedicle advancement flap in rats. Arch Vet Sci 2003;8(1):35-40.

19. Alferes FCBA, Lyra MC, Orgaes FAFS, Junior HL, Gonella, HA. Avaliação do etil-2-cianoacrilato $\left(\right.$ Epiglu $\left.^{\mathbb{R}}\right)$ na síntese de pele: estudo em ratos. Rev Bras Cir Plast. 2008;23(3):179-83.

20. D'Assumpção EA. Cola de cianoacrilatos de baixo custo em cirurgia plástica. Rev Soc Bras Cir Plast. 2008;23(1):22-5.

\section{Acknowledgments}

We dedicate this research to Professor Renato Pereira Lino in memoriam. To our great Master, all respects and affection by his valuable teachings and support during the course.

We thank César Nicolau da Costa MD, plastic surgeon and Sandra Ramos Magalhães for their consultancy to prepare this paper.

\section{Correspondence:}

Prof. Alcino Lázaro da Silva

Rua dos Otoni, 909/1707

30150-270 Belo Horizonte - MG Brasil

Tel.: (55 31)3221-3072 / 3273-0491

bardesiro@terra.com.br

cireniobarbosa@gmail.com

Received: July 12, 2012

Review: September 13, 2012

Accepted: October 10, 2012

Conflict of interest: none

Financial source: none

${ }^{1}$ Research performed at Surgical Technique and Experimental Surgery Division and Technical Operative and Video Surgery Unit "Professor Luiz Andrés Ribeiro de Oliveira", Medical Sciences Faculty of Minas Gerais (FCMMG), Brazil. 